\title{
Raiteiltaan suistunut utopia
}

\section{Kasimir Sandbacka, Utopia Derailed. Rosa Liksom's Retrospection of the Modern Project. University of Oulu Graduate School, Faculty of Humanities. Acta Universitatis Ouluensis B 154. Oulu, Oulun yliopisto, 2017,61 s.}

Kasimir Sandbackan väitöskirjatutkimuksen nimi Utopia Derailed. Rosa Liksom's Retrospection of the Modern Project ilmaisee osuvasti välittämänsä perusnäkemyksen Rosa Likosmin tuotannosta. Tutkimus näkee Liksomin tuotannon historialliseksi, yhteiskunnalliseksi ja kulttuuriseksi perustaksi modernin projektin kriisiytymisen. 1900-luvulla tämä uuden ajan alussa syntynyt ja valistuksen kaudella voimistunut projekti, joka on julistanut järjen, edistyksen ja vapauden välistä liittoa, on kokenut kovia. Ensin fasismin kauheudet ja Stalinin hirmuteot horjuttivat monien mielissä uskoa sen jatkumiseen. 1980- ja 1990-luvulla tapahtunut sosialististen kokeilujen romahtaminen ja amerikkalaistyylisen markkinakapitalismin kohoaminen maailmanvaltiaaksi näyttävät vieneen kokonaan pohjan pois siltä ja siihen sisältyviltä emansipaatioon viittaavilta utopistisilta visioilta. Ainakin näin tilanteen 1980- ja 1990-luvulla kokivat monet postmodernisteiksi julistautuneet taiteilijat ja vasemmistolaiset intellektuellit.

Ennen kuin vuonna 1958 Ylitorniossa syntynyt Rosa Liksom eli Anni Ylävaara aloitti kirjallisen tuotantonsa, hän oli 1980-luvulla ehtinyt opiskella Neuvostoliitossa, työskennellä Norjan kalatehtaissa ja asua Christianan vapaakaupungissa Kööpenhaminassa. Ensimmäisissä teoksissaan, lyhytproosakokoelmissa Yhden yön pysäkki (1985) ja Unohdettu vartti (1986) hän ei osoittautunut ainoastaan vähäosaisten ihmisten kuvaajiksi vaan hänen luomassaan maailmassa nämä rujosti käyttäytyvät ja itseään karheasti ilmaisevat hahmot näyttivät myös elävän vailla ihanteita ja toivoa paremmasta huomisesta. 1990-luvulta lähtien hänen tuotantonsa on ollut kasvavassa määrin itserefleksiivistä, omaa aiempaa tuotantoa ja kirjailijakuvaa tai taiteilijakuvaa parodioivaa, ja samalla se on laajentunut romaanin suuntaan.

Liksomin tuotannosta Sandbacka on valinnut lähemmän tarkastelun kohteeksi kolme teosta: lyhytproosakokoelman Bamalama (1993) sekä romaanit Kreisland (1996) ja Hytti Nro 6 (2011). Hänen tutkimuksensa muodostuu viidestä artikkelista, jotka ovat alun perin ilmestyneet vuosina 2012-2017. Artikkeleista kolme on englanninkielisiä ja kaksi suomenkielisiä. Artikkelit keskittyvät Liksomin teosten analysoimiseen ja tulkitsemiseen, mutta mukana on myös yksi Liksomin julkista imagoa ja hänen kirjailijakuvaansa analysoiva oivaltava kirjoitus. Näiden viiden artikkelin lisäksi tutkimuksen alkuun sisältyy laaja, noin 50 sivua pitkä selkeästi kirjoitettu johdanto, joka selvittää tutkimuksen tavoitteita ja 
kysymyksenasetteluja ja luo sille historiallista kontekstia. Samoin johdannossa tuodaan esiin joukko kokoavia peruskäsitteitä, jotka sitovat artikkeleita yhteen.

Väitöstutkimuksen pääkysymyksenä on sen selvittäminen, miten Liksomin teokset ja hänen julkinen kirjailijakuvansa käsittelevät modernin projektin 1900-luvulla saamia ilmenemismuotoja. Tämä pääkysymys koskettaa kaikkia viittä väitöskirjaan sisältyvää artikkelia. Sitä vastoin tutkimuksen alakysymykset ovat artikkelikohtaisia. Alakysymyksissään tutkimus tarkastelee sitä, missä mielessä Liksomin teokset omaksuvat ironisen asenteen modernin projektia ja sen utopistisia pyrkimyksiä kohtaan (ensimmäinen artikkeli), miten ne käsittelevät modernin projektiin sisältyviä ristiriitoja ja dikotomioita (toinen artikkeli) ja millainen on nostalgian rooli niissä (kolmas artikkeli). Lisäksi tutkimus pohtii sitä, mitkä modernin projektin puolet voitaisiin Liksomin teosten mukaan ottaa jatkokehittelyn ja parantelun kohteeksi tämän projektin postmodernikeskustelussa saaman kritiikin jälkeen (neljäs artikkeli). Lopuksi tutkimus tarkastelee vielä sitä, miten Liksomin julkisuuskuva "neuvottelee" modernismin ja postmodernismin diskurssien kanssa (viides artikkeli).

Tutkimuksessa on paljon alakysymyksiä, mutta ne liittyvät läheisesti toisiinsa ja tutkimuksen pääkysymykseen. Tutkimus on myös käsitteellisesti melko yhtenäinen eli tietyt peruskäsitteet toistuvat sen artikkeleissa. Metodiaan Sandbacka nimittää "kontekstuaaliseksi lähiluvuksi" tai kontekstuaaliseksi hermeneutiikaksi. Siinä on kyse siitä, että hän analysoi ja tulkitsee Liksomin teoksia suhteessa niiden historiallis-yhteiskunnalliseen kontekstiin. Hän ei kuitenkaan rekonstruoi Liksomin teoksille konkreettista kontekstia 1900-luvun historiaa ja yhteiskuntaa koskevien yksittäisten tutkimusten avulla, vaikka hän mainitsee, että 1900-luvun suuret tapahtumat, esimerkiksi fasismi, stalinismi, Neuvostoliiton lakkauttaminen, kapitalismin voittokulku ja tietyt suomalaisen yhteiskunnan tapahtumat, kuten 1990-luvun lama ovat keskeisiä tekijöitä Liksomin teosten kontekstissa. Tämän sijasta kontekstin käsite toimii hänen tutkimuksessaan abstraktimmalla tasolla.

Laatiessaan kontekstia Liksomin teoksille Sandbacka nojaa Theodor W. Adornon ja Max Horkheimerin "Valistuksen dialektiikkaan" (Dialektik der Aufklärung, 1944), joka käsittelee kulttuuri- ja historianfilosofian näkökulmasta valistuksen syntyä ja kehitystä sekä sen kivettymistä myöhemmin teknokraattiseksi ja välineelliseksi järjeksi. Adornon ja Horkheimerin teos puhuu myös siitä, miten valistus nousi järjen ja emansipaation nimissä vastustamaan uskontoa ja myyttejä, mutta se loikin oman mytologiansa, jossa keskeisiä ovat olleet tieteis- ja teknologiausko. Tähän voi lisätä sen, että valistus on sisältänyt muitakin ulottuvuuksia, joten sitä ei ole syytä palauttaa pelkäksi teknokraattiseksi ja välineelliseksi järjeksi. Näitä muita ulottuvuuksia ovat käsitelleet muun muassa Jürgen Habermas kirjassaan Theorie des kommunikativen Handelns (1981) ja Scott Lash kirjassaan Another Rationality. A Different Modernity (1999). Ne kiinnittävät huomiota siihen, miten esimerkiksi taiteelliset liikkeet, kuten romantiikka, symbolismi, surrealismi ja yhteiskunnalliset vaihtoehtoliikkeet, esimerkiksi 
ympäristöliike ja naisliike, ovat valistuksen ihanteiden pohjalta torjuneet kapea-alaisen teknokraattis-välineellisen rationaalisuuden. Sitä korjaamaan ne ovat kehitelleet sellaisia ajattelun, tuntemisen ja toiminnan muotoja, jotka ottavat paremmin huomioon yhtäältä ihmismielen ja järjen eri ulottuvuudet sekä toisaalta yhteiskunnallisen oikeudenmukaisuuden ja tasa-arvon vaatimukset ja luonnon monimuotoisuuden kunnioittamisen.

Liksomin teoksille kontekstia laatiessaan Sandbacka käyttää hyväksi myös Fredric Jamesonin teoriaa postmodernismista tai postmodernista. Sitä hän ei näe pelkkänä teoriana 1970- ja 1980-luvulla esiin murtautuneesta uudesta tyylisuunnasta vaan hänelle se on laaja periodi-käsite. Sellaisena se pitää "postmodernia" kulttuuria yhteiskunnan nykyisen kehitysvaiheen, globaalin kapitalismin, kulttuurisena vastineena, jossa keskeistä ovat historiantajun katoaminen ja vaikeus hahmottaa yhteiskuntaa kokonaisuutena, "totaliteettina". Sandbacka pohtii tutkimuksessaan lyhyesti myös sitä mahdollisuutta, että postmoderni kulttuuri olisi nykyisin korvautumassa "post-postmodernismilla" (J.T. Nealon) tai "metamodernismilla" (Timotheus Vermeulen, Robin van der Akker), joka ei vedä epistemologisesta ja ideologisesta skeptisismistä samanlaisia, lamaannuttavia johtopäätöksiä kuin postmodernismi. Pikemminkin metamodernismi on hyväksynyt epävarmuudessa elämisen olemassaolomme ja toimintamme lähtökohdaksi. Sandbacka soveltaakin tätä käsitettä varovaisesti Liksomin teosten tarkastelemiseen.

Analysoidessaan Liksomin teoksissa ilmenevää suhtautumistapaa historiaan ja moderniteettiin Sandbackan tutkimus operoi nostalgian, melankolian ja utopismin käsitteillä. Svetlana Boymin tutkimusten pohjalta väitöskirja jakaa nostalgian (koti-ikävän, kaipuun) "palauttavaan" ja "reflektiiviseen" nostalgiaan. Palauttava nostalgia on naiivia ja välitöntä, ja siinä - toisin kuin reflektiivisessä nostalgiassa - nostalginen subjekti ei tajua, että hänen kaipuunsa kohde ei välttämättä ole todellisuudessa sellainen kuin hän sen mielessään kuvittelee olevan. Melankolisessa surussa subjektin rakkaussuhde tai kiintymyssuhde on todellisuudessa päättynyt, mutta subjekti on edelleen patologisesti kiinni tähän suhteeseen liittyvissä tunteissa ja muistoissa; sitä vastoin vapauttavan surun (enabling mourning) läpikäynyt ihminen hyväksyy lopulta menetyksensä ja on sen jälkeen taas toimintakykyinen. Utopiat ovat konkreettisia kuvitelmia paremmasta maailmasta, kun taas "utopismi" on Sandbackalle halua kuvitella parempi maailma. Näiden käsitteiden ohella Sandbackan väitöskirja nojautuu Linda Hutcheonin tutkimuksiin postmodernismista ja ironiasta.

Edellä esitetyn käsitepakin näkökulmasta Kreislandin päähenkilö Impi Agafiina näyttäytyy ihmisenä, joka on vuoron perään elämyksellisesti osallisena kaikissa 1900-luvun suurissa ideologioissa - fasismissa tai äärioikeistolaisessa nationalismissa, neuvostoliittolaisessa kommunismissa ja amerikkalaisessa kapitalismissa - ja pettyy lopulta niihin. Kaikki nämä ideologiat pettävät romaanissa modernin projektin. Tässä mielessä Kreisland on osa postmodernismin piirissä esitettyä modernien totalisoivien ideologioiden kritiikkiä. Sen 
erityispiirteenä on se, että siinä säilyy samalla nostalginen kaipuu modernin projektiin sisältyneitä utopistisia impulsseja kohtaan. Varsinaisen utopiagenren piiriin Liksomin teoksia ei kuitenkaan voida sijoittaa.

Kreislandia Sandbackan väitöskirja analysoi kahdessa eri artikkelissa, joista jälkimmäinen tarkastelee myyttien tehtävää teoksessa. Artikkelin mukaan Kreisland hyödyntää ironiaa osoittaessaan, miten moderniteetilla on taipumus palata myytteihin. Romaanissa feminiininen toimija Impi Agafiina pyrkii vapautumaan myyteistä ja traditiosta, kun taas maskuliininen toimija Juho Gabriel edustaa moderniteetille vastakkaista kohtiota, esimodernia maailmaa. Romaanin ironialla kyllästetty loppu, jossa 1900-luvun suuret ideologiat läpikäynyt ja niihin pettynyt Impi Agafiina palaa takaisin Lappiin, kokee "neitseellisen raskaaksi tulemisen" ja avioituu kotikyläänsä jääneen Juho Gabrielin kanssa, on tällaisen moderniteettiin sisältyvän nostalgisen kaipuun ilmentymä. Sandbacka toteaa, että romaanin loppu varoittaa siitä, että myyttiset kuvitelmat menneestä alkukodista ovat kriisiaikoina toimineet usein fasististen ideologioiden käyteaineena.

Neuvostoliiton viimeisiin vuosiin ajoittuva Hytti Nro 6, joka kuvaa Rosa Liksomia muistuttavan suomalaisen nuoren naisen matkaa Moskovasta Mongoliaan, näyttäytyy Sandbackan tutkimuksessa moniulotteisena metafiktiivisenä romaanina. Sellaisena se kommentoi sekä Liksomin omaa, aiempaa tuotantoa että postmodernistista diskurssia. Erityisesti ironia, monimerkityksisyys ja skeptisismi ovat yhdistäneet Liksomin aiempaa tuotantoa postmodernismiin. Ironia sekä "suurten kertomusten" ja "virallisten totuuksien" epäileminen luonnehtivat myös kyseistä romaania, mutta siinä ne eivät enää viesti pelkästä torjunnasta vaan myös siitä, että nuo asenteet omaksuneet henkilöt - kuten romaanin päähenkilö ja hänen venäläinen hyttikumppaninsa Vadim - ovat vilpittömiä. Tältä pohjalta utooppisilla impulsseilla voi olla elämässämme ja toiminnassamme oma paikkansa, mutta niitä ei tule pitää varmoina ja lopullisina vastauksina kysymykseen siitä, miten ihmisten tulisi järjestää yhteiselämänsä. Tämän sijasta ne tulee asettaa jatkuvan kriittisen uudelleenarvioinnin kohteeksi.

Kasimir Sandbacka on tehnyt mielenkiintoisen ja inspiroivan väitöskirjan, joka on ehdottomasti tervetullut lisä suomalaiseen kirjallisuudentutkimukseen. Vaikka en voi täysin jakaa siinä esitettyä näkemystä moderniteetista, pidän siinä kehitettyä metodologiaa, kontekstuaalista lähilukua tai hermeneutiikkaa, tutkimustapana, jolle toivoisin olevan laajempaakin käyttöä kirjallisuudentutkimuksessa. Olennaista tässä tutkimustavassa on kulttuuri- ja yhteiskuntateoreettisen käsitteistön hyödyntäminen niin tutkimuskysymysten muotoilemisessa kuin tekstien analysoimisessa ja tulkitsemisessakin.

\section{Erkki Sevänen}

